\title{
Yersinia-specific antibodies in serum and synovial fluid in patients with yersinia triggered reactive arthritis
}

Outi Mäki-Ikola, Riitta Lahesmaa, Jürgen Heesemann, Riitta Merilahti-Palo, Riitta Saario, Auli Toivanen, Kaisa Granfors
IgA has been shown to be higher in synovial fluid than in serum in patients with Reiter's disease and ReA to indicate local antibody production. ${ }^{6}$ Further, in two studies with small groups of patients with salmonella and Chlamydia trachomatis triggered ReA, evidence for intra-articular production of specific antibodies was obtained. ${ }^{78}$ However, mechanisms leading to inflammation in synovium and the possible role for microbial antigens and antibodies in propagating these events is not understood.

In the present work, to further evaluate the role of bacterial antigens in triggering inflammation in the joint, we studied local antibody synthesis by measuring yersiniaspecific antibody levels in paired samples of serum and synovial fluid from patients with yersinia triggered ReA using an enzyme linked immunosorbent assay (ELISA). Antibodies of IgM, IgG and IgA classes, as well as antibodies of IgA subclasses and those containing secretory component (sIgA) were measured against LPS and/or sodium dodecyl sulphate (SDS) extract of whole Yersinia enterocolitica O:3 bacteria. Antibody levels were also measured by inhibition-ELISA against two of the plasmid encoded released proteins (RPs), which are proteins released into calcium deficient media by human enteropathogenetic strains of yersinia. ${ }^{9}$ The pattern of antigen specificity was further evaluated by inhibitionELISA with four monoclonal antibodies (MoAbs) directed against different parts of LPS, as well as by immunoblotting.

(Ann Rheum Dis 1994; 53: 535-539)

Certain infections of the gastrointestinal and urogenital tract, such as those caused by yersiniae and salmonellae, are sometimes followed by development of reactive arthritis (ReA), especially in patients carrying HLAB27. In the development of ReA host-microbe interaction is important, but the exact pathogenic mechanisms of arthritis are largely unknown. ${ }^{12}$

Despite negative attempts to culture bacteria from synovial fluids, there is strong direct evidence for the presence of microbial components, especially lipopolysaccharide (LPS), in the affected joints in patients with ReA. ${ }^{1-5}$ In addition, the concentration of total polymeric

\section{Patients and methods}

PATIENTS AND SAMPLES

Paired serum and synovial fluid samples from 29 patients infected with $Y$ enterocolitica O:3 were chosen from our large panel of samples collected from reactive arthritis patients for the present studies. Diagnosis of Yersinia infection was based in all patients on the typical clinical picture (diarrhoea, abdominal pain, vomiting and/or arthritis) and clearly increased levels of anti-yersinia antibodies detected by ELISA, ${ }^{10}$ in 16 cases, additionally, the pathogen was isolated from the stools. Age of the patients ranged from 13 to 72 years (mean 35), and the female to male ratio was 9:20. All patients developed ReA as a post infectious complication within three weeks after the onset of 
infection. Of the 27 patients tested, 23 were positive for the HLA B27 antigen. Serum and synovial fluid samples were collected simultaneously at 13 days to two months after the onset of infection; from one patient samples were taken at 8.5 months after the onset of infection. Synovial fluid aspirated from the knee was mixed with heparin $(50 \mathrm{IU} / \mathrm{ml}$ ), centrifugated at $200 \mathrm{~g}$ for 10 minutes and the supernatant was used for analysis. Both synovial fluid and serum samples were stored at $-20^{\circ} \mathrm{C}$ and studied simultaneously.

Serum and synovial fluid samples from nine patients with ReA triggered by microbes other than yersiniae (5, salmonellae; 2, Chlamydia trachomatis; 1, Y pseudotuberculosis and 1, unknown aetiology), from four patients with rheumatoid arthritis and from nine patients with swollen joints for other reasons (6 with swollen knee with unknown reason; 4 with chronic synovial inflammation with unknown reason, and 1 with colitis ulcerosa) served as controls.

\section{ANTIGENS}

As the source of RPs, plasmid-positive strain of $Y$ enterocolitica $0: 3$ was grown and RPs prepared as previously described. ${ }^{9}{ }^{11}$ The LPS was extracted from $Y$ enterocolitica O:3 using the phenol-water method. ${ }^{10}$ The SDS extract of whole $Y$ enterocolitica $0: 3$ bacteria was also used as antigen. ${ }^{8}$

ELISA FOR ANTI-YERSINIA ANTIBODIES

The ELISA procedures for IgM, IgG, IgA, IgA 1 and IgA 2 class yersinia antibodies and for yersinia antibodies containing secretory component (sIgA) have been reported earlier. ${ }^{1012}$ Patient serum or synovial fluid samples at 1:250 dilution were allowed to react with SDSextract of whole yersinia bacteria or LPS antigen attached to polystyrene microtitre plates. In IgM, IgG and IgA class assays alkaline phosphatase-conjugated swine antibody to human IgM, IgG and IgA (Orion Diagnostica, Espoo, Finland) were used to detect bound antibodies. In IgA subclass analysis MoAbs against IgA1 or IgA2 (Becton Dickinson, Mountain View, California) were used to detect bound antibodies, after which rabbit anti-mouse immunoglobulin (Miles-Yeda, Kiryat Weizmann, Rehovot, Israel) absorbed with human IgG and swine alkaline phosphatase conjugated anti-rabbit IgG (Orion Diagnostica) were used. The sIgA antibodies were detected using rabbit immunoglobulins to human secretory component (DAKO Patts A/S, Glostrup, Denmark) and alkaline phosphatase conjugated swine anti-rabbit IgG (Orion Diagnostica). Fresh p-nitrophenyl phosphate in diethanolamine- $\mathrm{MgCl}_{2}$-buffer solution (Orion Diagnostica) was used as a substrate and the reaction was stopped with $1 M$ sodium hydroxide. The optical density was measured with a Titertek Multiscan Photometer (Labsystems, Helsinki, Finland) at a wavelength of $405 \mathrm{~nm}$. Positive reference serum with high levels of yersinia antibodies was included on each plate. Antibody concentrations in the samples were expressed as relative units (enzyme immunoassay units; EIU): $1 \mathrm{U}$ is $1 / 100$ of the corresponding antibody concentration in the reference serum. Samples were tested as duplicates, and the results are expressed as the mean values.

MONOCLONAL ANTIBODIES (MOAbs)

The MoAb 9-200 recognises the $46 \mathrm{kD} / 57 \mathrm{kD}$ $\mathrm{RP}$ (YopM) and the MoAb PU-174 the $26 \mathrm{kD}$ $\mathrm{RP}$ (YopE) of $Y$ enterocolitica O:3. ${ }^{11} 13$ The MoAbs 2C1, 6B6 and $A 6$ react with the O-polysaccharide part of the LPS of $Y$ enterocolitica $\mathrm{O}: 3 .{ }^{3}{ }^{10}$ MoAb $2 \mathrm{~B} 5$ reacts with the outer core component of the $Y$ enterocolitica O:3 LPS. ${ }^{10}$ All these MoAbs have been described earlier.

INHIBITION- ELISAS WITH MOAbS

The procedure was similar to that described earlier. ${ }^{10} 11$ Polystyrene microtitre plates were coated with RPs (Yops) or LPS of $Y$ enterocolitica O:3. A $75 \mu \mathrm{l}$ portion of serum samples diluted $1: 10$ in RP-ELISA and $1: 10$ and 1:50 in LPS ELISA were incubated on the plates for 2 hours at $37^{\circ} \mathrm{C}$. After washings, a $60 \mu \mathrm{l}$ of the MoAb (at dilutions optimal for each MoAb; that is, 9-200 at 1:50, PU-174 at $1: 2000,2 \mathrm{C} 1$ at $1: 2000,6 \mathrm{~B} 6$ at $1: 15000,2 \mathrm{~B} 5$ at 1:800 and $\mathrm{A} 6$ at 1:800 dilutions) was added to incubate overnight at room temperature. After washings, $60 \mu \mathrm{l}$ of goat alkaline phosphatase-conjugated antiserum (absorbed with human serum) specific for mouse IgG and IgM (TAGO, Burlingame, California) was added at a dilution of 1:4000 and incubated at 3 hours at $37^{\circ} \mathrm{C}$. Quantitation by enzyme substrate was carried out as described earlier. Results were compared with values obtained by the MoAb alone (without serum sample) to calculate the inhibition percentage as described earlier. ${ }^{10} 11$

IMMUNOBLOTTING ANALYSIS OF IgG AND IgA CLASS ANTI-YERSINIA ANTIBODIES

The SDS-polyacrylamide gel electrophoresis of whole $Y$ enterocolitica $\mathrm{O}: 3$ bacteria and immunoblotting were carried out as previously described. ${ }^{14} 15$

\section{CONTROL ELISAS}

To compare serum and synovial fluid distribution of antibodies against other than the infecting microbe, the ELISAs for antibodies against Bordetella pertussis, tetanus toxoid, Candida albicans, rubella and measles were performed as described elsewhere. ${ }^{16-18}$

\section{STATISTICS}

Wilcoxon test was used for comparison of antibody levels in serum and synovial fluid. Spearman's correlation test was used to assess the degree of correlation between serum and synovial fluid antibody concentrations. 
Table 1 Antibody concentrations (in EIU) against sodium dodecyl sulphate extract of whole Yersinia enterocolitica O:3 bacteria in paired serum and synovial fluid samples of patients with yersinia triggered reactive arthritis

\begin{tabular}{|c|c|c|c|c|c|}
\hline & Serum & Synovial fluid & $P^{\star}$ & $\begin{array}{l}\text { Spearmann's } \\
\text { correlation } \\
\text { coefficient } \dagger / P\end{array}$ & $\begin{array}{l}\text { Number } \\
\text { of sample } \\
\text { pairs }\end{array}$ \\
\hline $\operatorname{Ig} M$ & $122 \cdot 8(67 \cdot 6)$ & $97 \cdot 9(76 \cdot 1)$ & 0.0002 & $0.88 / 0.0000$ & 25 \\
\hline IgG & $85.9(32.2)$ & $75.6(36.4)$ & 0.03 & $0 \cdot 74 / 0 \cdot 00003$ & 25 \\
\hline IgA & $176.8(99.4)$ & $151.6(110.5)$ & $0 \cdot 04$ & $0 \cdot 87 / 0 \cdot 0000$ & 25 \\
\hline IgA1 & $64.6(33.6)$ & $55.2(36.4)$ & NS & $0.65 / 0.0006$ & 23 \\
\hline IgA2 & $42 \cdot 4(44 \cdot 5)$ & $44 \cdot 2(59 \cdot 4)$ & NS & $0 \cdot 59 / 0 \cdot 0022$ & 23 \\
\hline sIgA & $76 \cdot 1(59 \cdot 8)$ & $51 \cdot 2(48 \cdot 6)$ & 0.0001 & $0 \cdot 90 / 0 \cdot 0000$ & 23 \\
\hline
\end{tabular}

Mean (SD) values are given.

EIU, enzyme immunoassay unit.

NS, not significant.

sIgA, IgA antibody containing secretory component

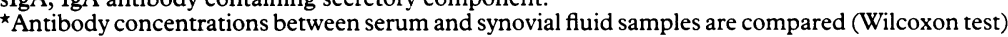
tBetween antibody concentrations in serum and synovial fluid samples.

Table 2 Inhibition of the binding of Yersinia enterocolitica O:3 lipopolysaccharide (LPS)-specific monoclonal antibodies (MoAbs) to Yersinia enterocolitica O:3 LPS by paired serum and synovial fluid samples from patients with yersinia triggered reactive arthritis

\begin{tabular}{lllllll}
\hline MoAb & Specificity & $\begin{array}{l}\text { Sample } \\
\text { dilution }\end{array}$ & $\begin{array}{l}\text { Inhibition \% in } \\
\text { serum/synovial fluid }\end{array}$ & $P^{\star}$ & $\begin{array}{l}\text { Spearmann's } \\
\text { correlation } \\
\text { coefficient }+/ P\end{array}$ & $\begin{array}{l}\text { Number of } \\
\text { sample pairs }\end{array}$ \\
\hline 2B5 & Outer core & $1: 10$ & $57 \cdot 6(29 \cdot 1) / 60 \cdot 2(28 \cdot 7)$ & NS & $0 \cdot 77 / 0 \cdot 0000$ & 23 \\
& of LPS & $1: 50$ & $37 \cdot 9(28 \cdot 4) / 35 \cdot 1(24 \cdot 9)$ & NS & $0 \cdot 95 / 0 \cdot 0000$ & 24 \\
A6 & O-polysaccharide & $1: 10$ & $53 \cdot 3(33 \cdot 2) / 52 \cdot 1(31 \cdot 2)$ & NS & $0 \cdot 82 / 0 \cdot 0000$ & 22 \\
& of LPS & $1: 50$ & $31 \cdot 9(31 \cdot 0) / 29 \cdot 1(27 \cdot 2)$ & NS & $0 \cdot 96 / 0 \cdot 0000$ & 24 \\
6B6 & O-polysaccharide & $1: 10$ & $71 \cdot 7(28 \cdot 6) / 69 \cdot 8(35 \cdot 5)$ & NS & $0 \cdot 70 / 0 \cdot 0002$ & 23 \\
& of LPS & $1: 50$ & $56 \cdot 0(35 \cdot 0) / 5 \cdot 7(35 \cdot 1)$ & NS & $0 \cdot 93 / 0 \cdot 0000$ & 24 \\
2 C1 & O-polysaccharide & $1: 10$ & $73 \cdot 1(30 \cdot 7) / 69 \cdot 9(37 \cdot 4)$ & NS & $0 \cdot 81 / 0 \cdot 0000$ & 23 \\
& of LPS & $1: 50$ & $58 \cdot 6(36 \cdot 5) / 54 \cdot 0(36 \cdot 3)$ & NS & $0.95 / 0 \cdot 0000$ & 24 \\
\hline
\end{tabular}

Mean (SD) values are given.

*Antibody concentrations between serum and synovial fluid samples are compared (Wilcoxon test). †Between antibody concentrations in serum and synovial fluid samples.

\section{Results}

DIRECT ELISA FOR ANTI-YERSINIA ANTIBODIES Paired samples of serum and synovial fluid from the patients with $Y$ enterocolitica $0: 3$ infection were studied for the presence of antiyersinia antibodies (table 1). In all assays the correlation between the antibody concentrations in serum and synovial fluid was good: Spearman's correlation coefficient was from 0.59 to 0.90 ( $\mathrm{p}$ from 0.0022 to 0.0001 ). The antibody levels against the SDS extract of whole bacteria as well as the LPS were significantly higher in the sera compared with the synovial fluid samples in IgM, IgG and IgA classes, as well as in sIgA ( $\mathrm{p}$ from $<0.04$ to $0.0001)$; especially clearly the difference was seen in the IgM and sIgA classes. In the IgA1 and $\operatorname{IgA} 2$ subclass analysis there were no differences in the antibody levels between the sera and synovial fluid samples. No significant differences were found between the absorbance values in the SDS extract ELISA and the LPS ELISA indicating that the majority of the antibodies are directed against the LPS part of the bacteria.

INHIBITION ELISAS FOR YERSINIA ANTIBODIES Paired samples of serum and synovial fluid from 17 patients with $Y$ enterocolitica $0: 3$ infection were used to inhibit the binding of MoAbs to $26 \mathrm{kD}$ and $46 \mathrm{kD}$ RPs. Nine of the serum samples and four of the synovial fluid samples are able to inhibit the binding of MoAb PU-174 to $26 \mathrm{kD}$ RP significantly more than sera taken from healthy controls [inhibition- $\%>$ mean $+2 \mathrm{SD}$ in controls]. ${ }^{11}$ The corresponding figures were eight for serum samples and 12 for synovial fluid samples when inhibition of MoAb 9-200 to $46 \mathrm{kD} \mathrm{RP}$ was studied. When the mean (SD) inhibition- $\%$ of all the serum or synovial fluid samples were studied, the serum samples were able to inhibit the binding of $26 \mathrm{kD} \mathrm{RP}$-specific MoAb 38.4\% (34.8), compared with $20 \cdot 3 \%$ $(29.9)$ inhibition with synovial fluid samples. Thus there were no statistically significant differences in the concentrations of antibodies to the MoAb PU-174-defined epitope of $26 \mathrm{kD}$ RP between the sera and synovial fluids. Accordingly, there were no differences in the ability to inhibit the binding of $46 \mathrm{kD} \mathrm{RP}$ specific MoAb to $46 \mathrm{kD} \mathrm{RP}$ between serum [mean (SD) $58.8 \%(28 \cdot 7)$ ] and synovial fluid [65.9\% (31.8)] samples.

Similarly, when paired serum and synovial fluid samples were studied, there were no significant differences in the antibody concentrations against the MoAb 2B5-, A6-, 6B6and 2C1-defined epitopes of $Y$ enterocolitica O:3 LPS between sera and synovial fluids (table 2). There was a good correlation between the antibody concentrations in sera and synovial fluids in all assays; Spearman's correlation coefficient was from 0.70 to 0.96 (p from 0.0002 to $0 \cdot 0000$ ).

IMMUNOBLOTTING

To study whether we can identify qualitative differences in the antibody reactivity to various yersinia antigens, paired serum and synovial fluid samples were analysed by immunblotting with whole $Y$ enterocolitica $\mathrm{O}: 3$ bacteria as antigen in the nitrocellulose sheet. Based on this extensive analysis, identical panel of $Y$ enterocolitica antigens was recognised by IgG and IgA of the serum and synovial fluid samples (figure).

\section{CONTROL ELISAS}

The antibody level in serum samples was higher than in synovial fluid samples when IgG class antibodies against tetanus toxoid, measles and rubella were studied. Also the level of IgM, IgG and IgA class antibodies against Candida albicans was higher in serum samples compared with synovial fluid samples (table 3 ).

\section{CONTROL SAMPLES}

Paired serum and synovial fluid samples from 22 control patients with other rheumatic diseases than yersinia triggered ReA were studied for the presence of yersinia-specific antibodies, as well as antibodies against the above mentioned control microbes. The yersinia antibody levels were always low. There were no differences in the antibody levels between sera and synovial fluids in IgM, IgG, IgA and sIgA class ELISAs using LPS as antigen, or in IgG and sIgA classes using SDS extract of whole bacteria as antigen. In IgM and IgA class with SDS extract antigen the antibody concentration was higher in serum 


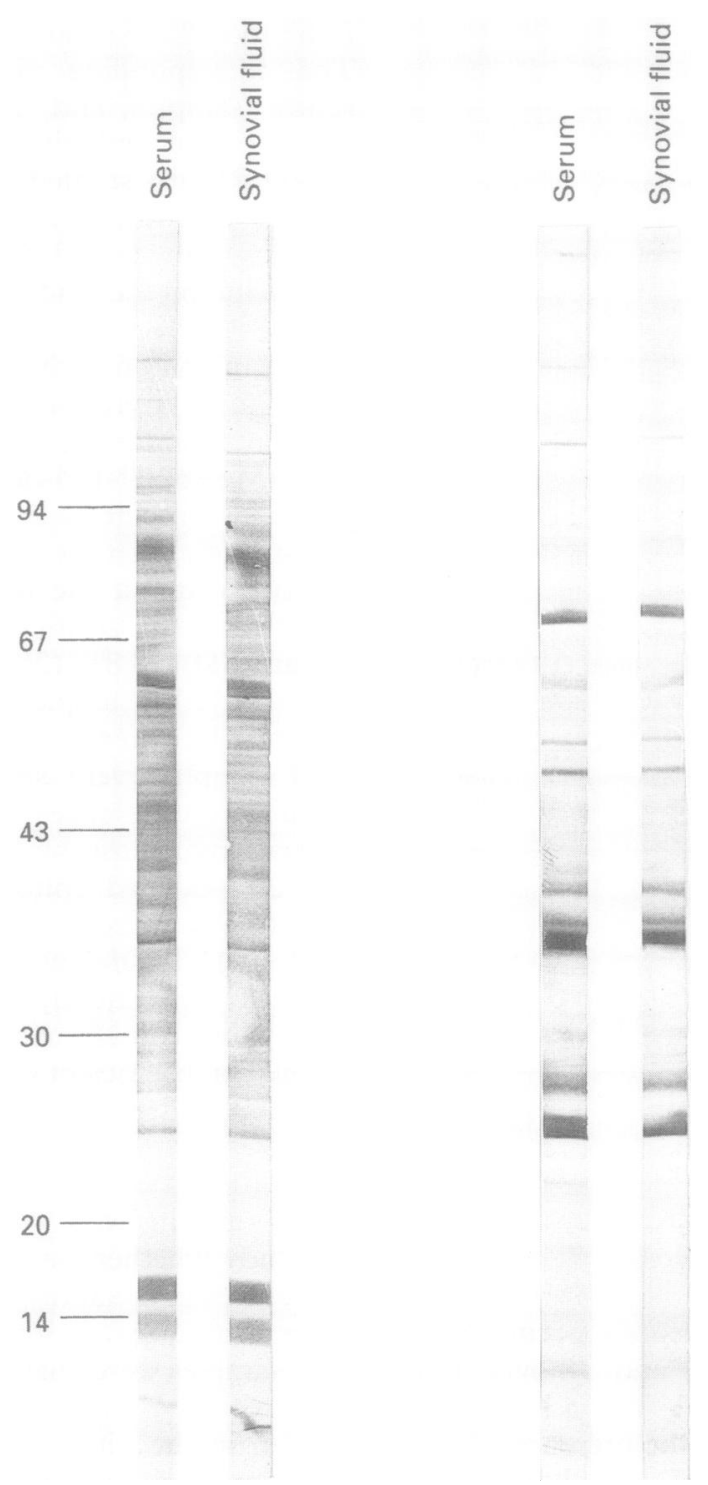

Immunoblotting analysis of serum and synovial fuid IgG response to Yersinia enterocolitica $O: 3$ in two patients with reactive arthritis showing that identical panel of $\mathrm{Y}$ enterocolitica antigens was recognised by the serum and synovial fluid samples.

compared with synovial fluid $(\mathrm{p}<0.05)$. The antibody level was higher in serum compared with synovial fluid also when antibodies against rubella $(p<0.0004)$, measles $(p<0.0003)$, tetanus toxoid ( $\mathrm{p}<0.0004)$, Bordetella pertussis $(\mathrm{p}<0.002)$ and Candida albicans $(\mathrm{p}<0.0003)$ for IgM, p $<0.0003$ for IgA and $p<0.0001$ for IgG) were measured.

Table 3 Antibody concentrations against control microbes in paired serum and synovial fluid samples of patients with yersinia triggered reactive arthritis

\begin{tabular}{|c|c|c|c|c|}
\hline & Serum & Synovial fluid & $P \neq$ & $\begin{array}{l}\text { Number } \\
\text { of sample } \\
\text { pairs }\end{array}$ \\
\hline 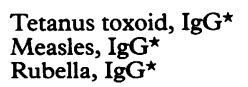 & $\begin{array}{l}10 \cdot 1(9 \cdot 2) \\
42 \cdot 5(30 \cdot 4) \\
49 \cdot 0(29 \cdot 7)\end{array}$ & $\begin{array}{c}7 \cdot 3(8 \cdot 0) \\
37 \cdot 1(33 \cdot 5) \\
39 \cdot 2(32 \cdot 5)\end{array}$ & $\begin{array}{l}<0.01 \\
<0.05 \\
<0.01\end{array}$ & $\begin{array}{l}19 \\
25 \\
25\end{array}$ \\
\hline $\begin{array}{l}\text { Candida albicans } \\
\text { IgM† } \\
\text { IgG† } \\
\text { IgA } \dagger\end{array}$ & $\begin{array}{l}0.559(0.226) \\
1.186(0.416) \\
0.538(0.241)\end{array}$ & $\begin{array}{l}0.370(0.205) \\
1.047(0.444) \\
0.421(0.249)\end{array}$ & $\begin{array}{l}<0.0005 \\
<0.01 \\
<0.005\end{array}$ & $\begin{array}{l}22 \\
22 \\
22\end{array}$ \\
\hline
\end{tabular}

Mean (SD) values are given

$\star$ EIU, enzyme immunoassay unit.

^EIU, enzyme immunc.

†Absorbance value.

\section{Discussion}

In the present study we demonstrate that in patients with yersinia triggered $\operatorname{ReA}$ yersiniaspecific antibodies in the synovial fluid mirror those in the serum as judged by concentration, by specificity or by distribution in antibody classes or subclasses ( $p$ always $<0.003$ for correlation). When there was a statistically significant difference in the antibody concentrations between serum and synovial fluid samples, the antibody level was always higher in serum compared to synovial fluid. These results do not speak for any strong local antibody production, but indicate that the majority of yersinia antibodies in the synovial fluid are derived from the circulation. The results from assays with microbes unrelated to yersinia infections as antigens support this concept. Accordingly, no significant differences were found in the antibody levels against Chlamydia trachomatis, Yersinia enterocolitica or Borrelia burgdorferi between serum and synovial fluid samples from patients with undifferentiated oligoarthritis. ${ }^{19}$ Further, the difference in antibody concentrations between serum and synovial fluid samples was biggest in IgM and sIgA (the largest immunoglobulin molecules in size) assays, which is in line with the above suggestion of filtration of the antibodies from circulation into the joint.

Controversially, we have recently found evidence for intra-articular antibody production of $\operatorname{IgA} 2$ subclass against salmonella LPS in patients with salmonella triggered $\operatorname{ReA} .{ }^{8}$ Most of the circulating IgA belongs to the subclass IgA1, whereas in locations close to mucosal surfaces, especially the distal gut where salmonella invades the mucosa, the number of $\operatorname{IgA} 2$ producing cells is increased. ${ }^{2021}$ Thus antibodies of IgA2 subclass in synovial fluid were thought to indicate mucosal origin. It was speculated that the high level of IgA2 class salmonella specific antibodies in the joint was a result of selective migration of IgA2-secreting lymphocytes from the distal gut mucosa to synovium, ${ }^{22}$ where the existing salmonella LPS may have stimulated local IgA2 class antibody production. ${ }^{4}$ However, yersinia penetrates the mucosa in the proximal part of the gut, where no increased number of IgA2 producing cells are seen. Thus if the intra-articular antibody production suggested in salmonella triggered $\operatorname{ReA}$ is subclass specific, the difference in the location of invasion between salmonella and yersinia may explain why $\operatorname{IgA} 2$ class anti-yersinia antibodies may not have been produced locally in the joints in patients with yersinia triggered ReA. It is, however, important to note that higher antibody concentrations are generally detected in the serum, as shown here and also, for example, in patients with rheumatoid arthritis. ${ }^{23}$ Therefore even if the concentration of antibodies in synovial fluid was lower than that observed in serum, the synovial fluid may have contained locally produced antibodies. Further, it is also possible that some of the synovial fluid antibodies are lost in the assays due to the formation of immune complexes and subsequent trapping in the cartilage. 
Likewise, it is possible that the finding of similar levels in serum and synovial fluid yersinia-specific IgA1 and IgA2 subclasses, as well as of IgA and IgG classes would be of some importance, since the differences between antibody levels in serum and synovial fluid in other immunoglobulin classes and in controls against other organisms are much more striking than in these mentioned tests.

The role of RPs in the pathogenesis of ReA has not been well studied yet. There are some indications for RPs to play some role in the pathogenesis of $\operatorname{ReA}: 1)$ patients with yersinia triggered $\operatorname{ReA}$ have more often antibodies against the $36 \mathrm{kD} \mathrm{RP}$ and higher concentrations of antibodies against the $26 \mathrm{kD} \mathrm{RP}$ in the beginning of the disease than the patients who recover from the infection without arthritis; $;^{11}$ 2) total amount of IgA class antibodies against RPs is significantly higher in arthritic patients in the beginning of the disease $;^{15} 3$ ) yersinia bacilli was demonstrated in the intestinal biopsy specimens of patients with yersinia-triggered $\operatorname{ReA}$ by immunofluorescence using monospecific rabbit antiserum to $46 \mathrm{kD} \mathrm{RP}^{24}$ and 4) strong T-cell reactivity to RPs was detected in synovial fluid samples taken from patients with reactive arthritis. ${ }^{25}{ }^{26}$ In the present study we could find no evidence for intra-articular antibody production against the two MoAb-defined epitopes of $26 \mathrm{kD}$ and $46 \mathrm{kD}$ RPs. The intrasynovial antibodies also against RPs may have therefore filtrated to the joint from the circulation rather than been produced locally. Thus the involvement of RPs in the pathogenesis of $\operatorname{ReA}$ remains open to speculation.

In ReA, microbial antigens enter the body via mucosal surfaces. Subsequently, microbial LPS is transported to the joints. ${ }^{1-5}$ Microbial antibodies are produced and may filtrate into the synovium from circulation, or as in case of salmonella triggered $\mathrm{ReA}$, they may be produced locally in the joints. ${ }^{8}$ Antibodies may also be transported to the joint as part of immune complexes, as immune complexes consisting of yersinia antigen and specific antibody are found in the circulation as well as in synovial fluid in yersinia triggered $\mathrm{ReA} .{ }^{27}$ The specific antibodies together with microbial antigens in the joint may participate in inflammation and tissue injury through complement activation. LPS may play an important role in these events, as a major part of yersinia-specific antibodies in serum and synovial fluid in patients with $\operatorname{ReA}$ were directed against LPS. Our previous studies also suggest a crucial role for LPS in the pathogenesis of ReA. ${ }^{1-4} 81028$

We thank Professor David T Y Yu for 2C1 and 6B6 monoclonal antibodies, Dr Rauli Leino for some of the patient samples and records, Raija Vainionpää for analysing the viral antibodies and Mrs Soile Niittoaho and Mrs Maija Salonen for technical assistance. Our study was supported by the grants from the Rheumatism Research Foundation, the Turku University Foundation, the Yrjö Jahnsson Foundation, th Sigrid Jusélius Foundation and the Finnish Academy, and by contract with the Finnish Life and Pension Insurance Companies.
1 Granfors K. Do bacterial antigens cause reactive arthritis? Rheum Dis Clin North Am 1992; 18: 37-48.

2 Mäki-Ikola $\mathrm{O}$, Granfors $\mathrm{K}$. Salmonella-triggered reactive arthritis. Lancet 1992; 339: 1096-8.

3 Granfors K, Jalkanen S, von Essen R, et al. Yersinia antigens in synovial-fluid cells from patients with reactive arthritis. $N$ Engl f Med 1989; 320: 216-21.

4 Granfors K, Jalkanen S, Lindberg A A, et al. Salmonella lipopolysaccharide in synovial cells from patients with reactive arthritis. Lancet 1990; 335: 685-8.

5 Hammer M, Zeidler H, Klimsa S, Heesemann J. Yersinia enterocolitica in the synovial membrane of patients with Yersinia-induced arthritis. Arthritis Rheum 1990; 33: $1795-800$.

6 Inman R D, Johnston M E A, Klein M H. Analysis of serum and synovial fluid IgA in Reiter's syndrome and reactive arthritis. Clin Immunol Immunopathol 1987; 43: 195-203.

7 Hughes R A, Treharne J D, Keat A C. Comparison of serum and synovial fluid chlamydial antibody titres. Arthritis Rheum 1989; 32: s113 (c129).

8 Mäki-Ikola O, Yli-Kerttula U, Saario R, Toivanen P, Granfors K. Salmonella-specific antibodies in serum and synovial fluid in reactive arthritis. $\operatorname{Br} \mathcal{F}$ Rheumatol 1992; 31: $25-9$.

9 Heesemann J, Gross U, Schmidt N, Laufs R. Immunochemical analysis of plasmid-encoded proteins released by enteropathogenic yersinia sp. grown in calcium-deficient media. Infect Immun 1986;54:561-7.

10 Granfors K, Ogasawara M, Hill J L, Lahesmaa-Rantala R, Toivanen A, Yu D T Y. Analysis of IgA antibodies to lipopolysaccharide in yersinia-triggered reactive arthritis. fInfect Dis 1989; 159: 1142-7.

11 Mäki-Ikola O, Pulz M, Heesemann J, et al. Antibody response against $26 \mathrm{kD}$ and 46 kilodalton released proteins of yersinia in yersinia-triggered reactive arthritis. Ann Rheum Dis 1992; 51: 1247-9.

12 Granfors $\mathrm{K}$, Toivanen A. IgA-anti-yersinia antibodies in yersinia triggered reactive arthritis. Ann Rheum Dis 1986; 45: $561-5$.

13 Heesemann J, Kalthoff H, Koch F. Monoclonal antibodies directed against plasmid-encoded released proteins of enteropathogenic Yersinia. FEMS Microbiol Lett 1986; 36: 15-9.

14 Ståhlberg T H, Heesemann J, Granfors K, Toivanen A. Immunoblot analysis of IgM, IgG and IgA responses to plasmid encoded released proteins of yersinia enterocolitica in patients with or without yersinia triggered reactive arthritis. Ann Rheum Dis 1989; 48: 577-81.

15 Lahesmaa-Rantala R, Heesemann J, Lehtonen O-P, Granfors $K$, Toivanen A. Avidity of antibodies against released proteins of yersinia spp: comparison of patients released proteins of yersinia spp: comparison of patients
with or without reactive arthritis. Ann Rheum Dis 1989; 48: $1003-6$.

16 Ruuskanen O, Viljanen M K, Salmi T T, Lehtonen O-P, Kouvalainen K, Peltonen T. DTP and DPT-inactivated polio vaccines: comparison of adverse reactions and IgG, IgM and IgA antibody responses to DTP. Acta Paediatr Scand 1980; 69: 177-82.

17 Salonen J, Vainionpää R, Halonen P. Assay of measles virus IgM and IgG class antibodies by use of peroxidaselabelled viral antigens. Arch Virol 1986; 91: 93-106.

18 Kaukonen K, Savolainen J, Viander M, Terho E O. Characterization of Aspergillus umbrosus carbohydrate antigens by biotinylated lectins and IgG response to mannan/mannoprotein antigens in patients with farmer's mannan/mannoprotein antigens in pa

19 Sieper J, Braun J, Brandt J, et al. Pathogenetic role of Chlamydia, Yersinia and Borrelia in undifferentiated oligoarthritis. F Rheumatol 1992; 19: 1236-42.

20 Crago S S, Kutteh W H, Moro I, et al. Distribution of IgA1IgA2-, and J chain-containing cells in human tissues. fImmunol 1984; 132: 16-8.

21 Kett K, Brandtzaeg P, Fausa O. J-chain expression is more prominent in immunoglobulin A2 than in immunoglobulin Al colonic immunocytes and is decreased in globulin Al colonic immunocytes and is decreased in disease. Gastroenterol 1988; 94: 1419-25.

22 Salmi M, Granfors K, Leirisalo-Repo M, et al. Selective endothelial binding of interleukin-2-dependent human T-cell lines derived from different tissues. Proc Natl Acad Sci 1992; 89: 11436-40

23 Musiani M, Zerbini M, Ferri S, Plazzi M, Gentilomi G, La Placa M. Comparison of the immune response to EpsteinBarr virus and cytomegalovirus in sera and synovial fluids of patients with rheumatoid arthritis. Ann Rheum Dis 1987; 46: 837-42

24 Hoogkamp-Korstanje J A A, de Koning J, Heesemann J. Persistence of yersinia enterocolitica in man. Infection 1988; 16: 81-5

25 Lahesmaa R, Yssel H, Batsford S, et al. Yersinia enterocolitica activates a $\mathrm{T}$ helper type 1-like $\mathrm{T}$ cell subset in reactive arthritis. $\mathcal{F}$ Immunol 1992; 148: 3079-85.

26 Lahesmaa R, Leirisalo-Repo M, Söderberg C, et al. Preferential TCR V $\beta$ usage by Yersinia antigen-reactive $\mathrm{T}$ cells isolated from a patient with reactive arthritis. Arthritis Rheum 1993; 36: S151.

27 Lahesmaa-Rantala R, Granfors K, Isomäki H, Toivanen A Yersinia specific immune complexes in the synovial fluid of patients with yersinia triggered reactive arthritis. Ann Rheum Dis 1987; 46: 510-4.

28 Mäki-Ikola O, Leirisalo-Repo M, Kantele A, Toivanen P, Granfors K. Salmonella-specific antibodies in reactive arthritis. F Infect Dis 1991; 164: 1141-8. 